\title{
The Role of International Cooperation in Community-based Tourism
}

\author{
Andrea Giampiccoli \\ TREES (Tourism Research in Economic, Environs \& Society), North-West University (Potchefstroom Campus), \\ Private Bag X6001, Potchefstroom, 2520, South Africa. \\ Email: andrea.giampiccoli@gmail.com \\ Oliver Mtapuri \\ University of Limpopo, Turfloop Graduate School of Leadership, \\ P.O. Box. 759, Fauna Park, 0787, South Africa. \\ Email: oliver.mtapuri@ul.ac.za
}

\section{Doi:10.5901/mjss.2014.v5n4p638}

\section{Abstract}

This paper investigates the role of tourism in rural development specifically with reference to community-based tourism (CBT) as a rural community development approach. A case study method is to unpack a CBT development project in which the influence of international actors is pronounced. Participant observation was used for data collection including reviewing of literature. This paper shows the trajectory of a CBT project being compromised by the influence of international capital within a neo-liberal framework. A major contribution of this paper is the proposition of a CBT model that articulates and delineates the role of external players and the ingredients of a potentially viable CBT project. These ingredients include: convenience to community, primacy of local culture, bottom-up structures, autonomy, self-governance, the promotion of community cohesion, respect for and preservation of the environment, enhancement of the health and educational well-being of communities.

Keywords: Tourism, community-based tourism, community development, international cooperation, Mpondoland, South Africa.

\section{Introduction}

Community-based tourism (CBT) has been championed as a tool to improve the livelihoods of poor people by creating development opportunities. Writers such as Telfer and Sharpley (2008:115) question the ownership and control of community-based tourism ventures particularly whether they are under local elites or external tourism development agents.

Today, tourism is also used in international cooperation as a strategy to promote the development of poor communities. In this context international cooperation for development is a relevant source of funding for international tourism expansion (Lindberg et al, 2001:508) and an agency such as the World Bank strives to expand its role in the tourism sector (Dickinson in World Bank, n.d.). Importantly, international cooperation for community development in poor communities of developing countries is increasingly seen as promoting tourism in order to alleviate poverty (Spenceley, 2008:286). As such, community-based tourism, combines issues of community development, poverty alleviation, cultural heritage and conservation (Equations, 2008:62). It is conceived as having the potential to break the structural dependency aspects of tourism, which are based on hegemonic power that is wielded by tour operators or social elites (Timothy, 2002:150). Therefore, CBT is conceived as a specific tool to promote holistic community development and as a form of sustainable tourism development in comparison to the usual mass tourism.

The rationale and justification of this paper stems from the fact that there is a need to study tourism in its political and geographical dimensions. There is increasing awareness on the topic of CBT with numerous articles and books dedicated to different aspects regarding the relationship between globalization, neo-liberalism, hegemonic tourism forms and community development (See, for example, ; Hall, 2007; ; Reid, 2003; Scheyvens, 2002; Sharpley and Telfer, 2002). However, a lot still remains to be explored. This paper explores pertinent issues on the relationship between international cooperation, CBT and community development in a contemporary policy framework. It sketches out and exposes within the same conceptual framework of CBT models an international cooperation CBT project. It lays bare the advantages and disadvantages of international cooperation where its influence turns its beneficiaries into victims (losers) instead of benefiting from the intervention because they become victims of it. 


\section{Materials and Methods}

In writing this paper, two types of data were gathered, namely first-hand through participant observation by the principal author as well as from available public documents, which formed the basis upon which this case rests. Using participant observation, the principal author observed the infrastructure of the facilities, and the tourists who were coming and going and experiencing the trails and staying in the CBT Village Based tourism Accommodation (VBA). He also corresponded with key informants such as a gatekeeper in the village. The principal author visited the case study area on a regular basis from 2004 to date for different lengths of stay (from week-ends to months) staying in the villages with the local community.

The documentary review provided information on funding procedures as well as the type of partnership as obtaining in the Mid-Term Review. The consultancy reports provided insight into the actors involved in the evaluation and the links to the home countries of the consultants and the project funders and so forth. Thus, the objectives of this study were two-fold, namely: to expose the archetypal characteristics of international cooperation, which is circumscribed by the neo-liberal global milieu; and to develop an alternative model of CBT projects depending on their level of communitycenteredness.

\section{Mpondoland: A Case Study from South Africa}

\subsection{Introduction and Background to the Case}

This case study is situated within the Mpondoland section of the Wild Coast SDI, a mostly coastal area in the Eastern Cape. The birth of the project of this case study is a consequential development of the locally developed Amadiba project (or Amadiba Adventures), which started in 1997 with the participation of the Amadiba people and the local authorities leveraging the support of Ntsika Enterprise Promotion Agency (Wild Coast Community Tourism Initiative, n.d.). Amadiba Adventures was initially facilitated by a local South African non-governmental organisation (NGO), (Pondo Community Resources Optimisation Programme (PondoCROP). It was thereafter under the overall control of Amadiba Coastal Community Association (ACCODA) (Ntshona and Lahiff, 2003) and it was a community-based initiative (AmaMpondo Trails Brochure, n.d.). The Amadiba project created a blueprint for further expansion of community ventures on the Wild Coast (Wild Coast community tourism initiative, n.d.). The Amadiba project extension received the support and intervention of an external donor, the European Union (EU), that is, as a consequence of the Amadiba success as well as the many awards which the projects obtained (Wild Coast Community Tourism Initiative, n.d.).

Ntshona and Lahiff (2003:2 and 40) highlight some of the key features of the Amadiba trail project as follows:

- It is an ecologically sensitive community-based tourism project funded by the European Union;

- Involves Amadiba people in the processes of planning, implementation, management and decision making;

- The benefits therefore are intended to accrue primarily to the Amadiba community;

- It has identified 25 hiking trail sites and 12 other campsites along the Wild Coast for potential development by communities themselves or in partnership with commercial operators;

- Serves as a nationally and internationally acclaimed model for the extension of the trail along the length of the Wild Coast.

The official Amadiba Adventure brochure seems to encapsulate the 'perfect' CBT understanding where ownership, management and spread of benefit are paramount.

The Amadiba trail has been richly rewarded with positive comments by entities such as the International Union for the Conservation of Nature (IUCN) and Fair Trade Tourism Initiatives, while an audit by the South African Department of Environmental affairs and Tourism (DEAT) judged the Amadiba Trail the "most significant operating community tourism project in South Africa" (AmaMpondo Trail Brochure, n.d.). Importantly, the Amadiba trail is highly rated as a model for community-centred tourism (AmaMpondo Trail Brochure, n.d.).

The advent of the EU as both an international and external actor in the project produced some unintended outcomes, as shall been seen from this exposition.

For example, substantial funds were injected into the Amadiba project creating "pressure on the trail to conform to certain standards drawn largely from the world of private business" (Ntshona and Lahiff, 2003:41). In addition Ntshona and Lahiff (2003:42) also note that the jargon and discourse has undergone a shift, such as the switch from "staff" to "service providers", and from "project" to "business", "reflecting a change in attitude rather than in substance". Moreover, Ntshona and Lahiff (2003:42) also caution that the "top-down manner in which the restructuring process was initiated and 
implemented adds weight to the opinions of 'service providers' that they now work for a conventional business over which they have little control". Clearly, a shift of CBT development strategies seems to have occurred since the advent of the EU in the project.

Based on this analysis, among other conclusions on their study of the Amadiba project, Ntshona and Lahiff (2003:43) suggest the following:

- There is a crucial role that external agents can play in identifying and initiating community based projects;

- NGOs are best suited to fulfill this role purely due to "open-ended nature of the relationship and the uncertainty of financial returns";

- It is not the amount of money that is available that is key to this relationship, but its quality and duration;

- It is neither private interests nor donors who can play this role effectively;

- Private firms and donors have the potential to scuttle the process as a result of tight schedules and high expectations of urgent financial returns.

From how such donor-funded projects operate, Ntshona and Lahiff (2003) learn that while external funding can help a project grow, prospects of changing the character of the said project are also great and increased overheads arising from expansion in donor funding and not from an own-revenue base are detrimental to the project's growth and its sustainability (Ntshona and Lahiff, 2003:44). Thus, in as much as external cooperation in community-based project is welcome, it should follow specific local contexts and models and not introduce characteristics of an "alien" context, which could drastically change its face and even jeopardize its long-term sustainability.

It is fundamental to observe the comments on the Amadiba trail by an EU source that also emphasizes community driven development. This extract on the Amadiba Trail is well documented after the original Amadiba Trails (of 1997) and the EU (as from the year 2000) when the projects started. Therefore there is sufficient knowledge on both projects. For instance, the ACP-EU Courier (2002) states that: "Amadiba Adventures [...] aims to protect environmental resources, develop skills and foster community driven economic development. As one of the programme managers, Gernott Ott, explains: 'The aim of the exercise is fairly simple: to improve the quality of life of people living in one of South Africa's poorest regions by setting up sustainable tourism projects, managed by the communities themselves"' (ACP-EU, 2002). Nevertheless, the same document (ACP-EU, 2002:82) seems to suggest prophetically that there is a neo-liberal regearing of the project in its expansion; there are difficulties being faced from the management of the project the EU and South African entities (instead of local management as CBT upholds) and possible differences in ideas on possible project trajectories into the future and there are issues of external pressure, as well as issues such as the possible role of the mining sector in the area with the potential to jeopardise tourism (see Enslin, 2006). Of course, undertaking such a project can have its difficulties. The distance between the Wild Coast, Pretoria and Brussels, sometimes conflicting ideas and the commercial and industrial pressures do not always make things easy (ACP-EU, 2002:82).

Another project (second development node), within the EU-supported Wild Coast project, which was supposed to be created and developed along the lines and philosophy of the original Amadiba project (before the EU intervened) was called the AmaMpondo (or Pondoland) trail from AmaMpondo - Mpondo people, the tribe living in the area. The project is supposed to produce two main CBT development outcomes: first, CBT lodges, which entails the construction of proper lodges to be owned and managed by the community; and second, village-based CBT accommodation (VBA), which offer home-stay accommodation and which is expected to provide a few basic improvements, especially regarding toilets and showers (MTR, 2003; PondoCrop, 2002).

For CBT projects to prosper and be able to promote holistic community development, they usually need proper facilitation with regard to three basic facilitative ingredients: infrastructure (accommodation facilities, water system and so on); training of community members in different aspects of CBT management; and marketing to attract tourists. In CBT, the latter (marketing and attracting tourists) is one of the key possible and viable areas of partnership with the private sector because marketing is usually the reason behind the failure of most CBT ventures (Hayle, n.d.). The outcome of the project was that infrastructure was not completed, because after about five years, in 2005, only one camp (out of a total of six of the planned lodges/camps structures) was constructed; one is close to completion, one is about half way and three could not be started at all (Giampiccoli, 2010). Data on training of people from the MTR (2003) show that a good number of people were trained: 375 people were trained up to 2004 in sectors mostly correlated to leadership skills and awareness and natural resource management with very brief training sessions (of a duration of between four days and three months) while only a very small number (13 or 3.5\%) have undergone long-term training (of more than one year's duration) specifically in natural resource management (Giampiccoli, 2010:196). Furthermore, the ownership of the tourism venture is an important ingredient for empowerment and sustainability.

What is relevant is the different interpretations and use of CBT projects by different actors. This was also reported 
by the independent consultancy while writing their Mid-Term Review of the project. The Mid-Term Review is quite illuminating as it notes conflict of development ideologies within the programme (MTR 2003:16). In addition, because this was a pilot project, it should have tested the various options to determine the circumstances under which each option would be the most successful in achieving the objectives of the project, because such contrasts could then be viewed positively in that they could encourage diversity of enterprise models needed for a pilot project (MTR, 2003:16). To note that the Mid-Term Review was written by a German based consultancy (GOPA Consultants) and CHL Consulting Group, who were in charge of overseeing the management and coordination of the project. Both were European-based. This is understandable because the EU separately issued an international competitive tender to institute the project management unit (PMU) to supervise the programme (MTR, 2003).

For instance, the project was conceived to run in a wholly community-driven approach involving the private sector. However, two different approaches/philosophies concerning CBT were followed by different project actors, as was identified in the Mid-Term Review (MTR, 2003). One approach focused on setting up the community as full owners of all facets of the tourism project, that is, a community-driven approach that then involves the private sector. However, the second approach outlined in the financing agreement advocated the use of a private sector-driven approach that ensured optimum community participation (MTR, 2003:16). The two approaches are almost opposing. The first starts with the community and then evaluates private sector involvement. The second, on the other hand, begins with the private sector who will progressively determine community involvement in the project. A third approach of CBT, not mentioned in the Mid-Term Review, is to generate a tourism venture fully owned and managed by the community without the pre/post intervention of the private sector, but autonomous and/or linked to public structures (although the private sector could be involved as an external marketing and/or procurement partner). This latter approach is perhaps a more radical approach and is in all probability closer to the original concept of CBT, deriving its source from the alternative development approaches of the 1970s. The clash between two recognised CBT philosophies is documented within the Mid-Term Review (2003), which also emphasises the project management unit (PMU) approach whose objectives were "developing operational partnerships with the private sector [which] is a key element within the overall PMU brief" (PMU TOR in MTR, 2003:42).

Similar lines in understanding CBT development have been advanced by Ramsa and Mohd (2004:587) that suggest that if it is not possible to avoid the involvement of major tourism companies, the ideal limit has been clearly stated and "in partnership, the private sector will bring in the tourists, while the community manage their own facilities and activities". It is worth noting that Gosovic (2000:450) has identified the use of "partnership" as one of the "repeated buzz words and phrases in contemporary international and development-related discourse".

Interestingly, the Tourism Planning Framework for the O.R Tambo District Municipality, the area within which the case study lies, supported by the EU Wild Coast Programme, commented on the role of the private sector and the CBT model, a seemingly pro-private sector approach also with little regard to the historical, socio- and political context of South Africa. The document (this document was written by a private consultancy, Peter Norton and Associates cc, and has been supported by The EU Wild Coast Programme) states that: "The private sector has a very important role to play, and a significant amount of effort should go into establishing more effective working relationships with existing private sector operators (even if they are mostly white) and in developing black entrepreneurs in tourism (as opposed to focusing too much on the community tourism model) (Norton, 2003: 32).

\section{Results and Discussion}

The AmaMpondo (lodges) trail is (was) very important for the development of the local communities. It is the communityowned lodges, more than home-stay accommodation, which have greater potential to attract larger numbers of tourists who have the capacity to pay high accommodation rates; and at the same time, which have the ability to produce more community empowerment. This point is critically important if the motive is the advancement of communities. Novelli and Gebhardt (2007), in relation to their study in Namibia, also suggest the development of an innovative type of CBT enterprise, the 'Community Lodges'. This is because small-scale community enterprises comprising of campsites had, overall, generated poor financial returns; and the joint ventures with commercial partners, while being financially rewarding, created few opportunities for community empowerment (Novelli and Gebhardt, 2007:457).

In fact the MTR (2003:42) states that "[t]he PMU has developed a close relationship with the Wild Coast Holiday Association (WCHA) [which] is made up of twenty-one members. In discussion with the Chairman of WCHA, in Umtata, it was noted that collaborative relations with PondoCrop as the community enterprise development NGO, was weak. This seemed to be related to an under-appreciation of the role of the private sector in the community-based enterprise 
development approach being undertaken by PondoCrop". Here a clear link between political and economic hegemony seems to be at work. It seems clear that the common ideology between the PMU and the WCHA, the private sector association of the region, reflected a contrasting vision to the community-oriented approach of an NGO such as PondoCrop.

The AmaMpondo Trails project was meant to follow a CBT model of local development (embracing national Government, local NGOs and local community) owned and managed by the community. What can be surmised from the foregoing is that the advent of management by external international actors such as the EU and consultants has the effect of shifting the project towards a neo-liberal approach of partnership and private investment. If the EU project was intended to be a CBT project, events worked together to create an outcome in which the AmaMpondo trails (lodges) saw the linking of a private sector tourism venture with the local communities in partnership. Partnerships, instead, should be supportive as external "help" to facilitate fully own and managed CBT ventures or to attract tourists, but not to be within the CBT itself in project execution as Giampiccoli (2010:263) argues: "Had this model been followed in the current case study, the campsites/lodges would have remained under the total control and management of the community and could have been linked with an external company for marketing and procurement of tourists only. This is very different from a complete change of control over the campsites/lodges themselves, as in fact happened in the AmaMpondo case".

The suggestion from the independent consultancy's review follows a similar line by giving priority to private sector involvement and thereafter involving communities instead of prioritizing the community centeredness of the process. Clearly, CBT development conceived in these terms is a form centering around private investment (and return) and not around community development, which focuses on self-reliance and empowerment. It is a framework that propagates continuing dependency where private investors use community resources as a tourism attraction for commercial gain and perhaps to be thrown away when used up or depleted. Yet, CBT should use community resources within the context of a CBT model that strives for community self-reliance and empowerment with a long-term view on sustainability. That is the CBT model that this paper advocates and that is recognized as its original meaning and contribution to an alternative development approach that breaks away from the structural grasp of neo-liberalism. On the contrary, this example shows the intrusion of neo-liberal strategy that shifts the original intent of the project and hijacks it.

The development of the VBA Trail, which was supposed to be community-inclusive and community-oriented, has, however, suffered major interruptions because of the project management. Through participant observation (during the period 2004 - 2006) the principal author observed that in the villages that were involved in the project, very simple things such as toilets and showers were initiated but were never completed. Furthermore, the VBA Trail has not been a success and has been practically abandoned along the way by the project management (Giampiccoli, 2010). However, the demise of the VBA has not been complete. To illustrate this, a number of local people directly or indirectly involved in the initial VBA, when confronted by the prospects of a demise of the project, re-organised the project in a more modest way with their own capacities and resources (Giampiccoli, 2010). The village of Noquekwane has, by far, been the most successful to craft its own VBA development, although the accommodation venture has had minimal impact compared to other services (local food, local guided tours and so on). A possible reason for this success could be the proximity of Noquekwane to Port St. Johns, which has exposed the community to many years of interaction with the tourism sector allowing them to better understand and relate to the tourism sector (Giampiccoli, 2010). In fact, the community formed an external partnership with a private company to bring tourists to enjoy and experience the village's CBT activities. Personal observation and communications of one of the authors at village level show evidence supporting this observation. For instance, using the horses obtained through the AmaMpondo Trail project, the village CBT was able to build a relationship with external private companies in the town of Port St. Johns such that private companies that provide tourist accommodation are now delivering tourists to Noquekwane for horse trails around the area, as well as for meals. This has been working well enough. One of the authors personally witnessed a number of tourists coming from a backpacker lodge in Port St. Johns linked to the community VBA of Noquekwane. The backpacker lodge brings the tourist to the horse trail (or, if they have less time, the hiking trail) managed by the Noquekwane community VBA. The community VBA offers the tourist the trail and a local meal (if they want it).

In the Wild Coast case is has been noted that, although comprehensive community participation is essential, political structures are inconclusive towards the proper facilitation of community development strategies that allow participation in the mainstream tourism economy. ,

Ideally, Government institutions, playing a facilitative role should be at the forefront of the process, coming together with local community-based organisations in implementing CBT projects.

In this case, the project management shifted the CBT lodges, which were a fully community-owned-operated model to a partnership model, with the inclusion of a private company in the management of the lodges while the 
community VBA was left to wilt away by the project management.

In relation to poor communities, it should be noted that the marginal and/or poor are usually in a weak position due to the lack of human and capital resources. There is a tendency by the private sector, because of sheer power, to negotiate terms favourable to them. This support should be underpinned by policy legislation and institutional support consisting of dedicated offices to deal with the industry matters and the unequivocal promotion of empowerment, selfreliance and sustainability by the public sphere.

Given the above, we propose the following CBT model: The CBT project must be convenient and fitting for communities in terms of location, needs, and plans. To that end, it must be based on local culture and practices, skills, resources and capacities. In addition, it must be accessible in terms of bottom-up structures of management that allow communities to have their voices heard such that it liberates rather than domesticates communities. This implies that subjecting very disadvantaged communities to near-slavery conditions should be shunned by all concerned. Furthermore, the model we posit must provide communities with independence, self-governance and self-determination. It must facilitate full ownership and management of the CBT ventures by poor community members (allowing only for possible external partnership), therefore local community members must be the main beneficiaries. The role of external players should be facilitative, offering mentorship and coaching, marketing and the promotion of the CBT ventures, in circumstances of mutual respect if the assistance has the motive to empower and help communities sustain themselves. This recognizes that if funding is meant to benefit private business, let it be known upfront and the form and content of the CBT project takes a different trajectory. By extension, this means that it must not promote dependency and exploitation of communities by external partners. Rather, it can serve as a pivot and training ground to promote wider community development. It promotes the values and ideals of self-reliance, empowerment and sustainability. Deepening the perspective, our CBT model suggests promoting inclusion and empowerment of specific groups (eg women, disabled) and a change of principles from competition to co-operation within and outside the community and by and large engendering a spirit of collective entrepreneurship for the good of the community. As a result, this includes both direct and indirect beneficiaries through community projects supported by the CBT revenues. Lastly, it promotes the role of public entities as supportive and facilitative agents in community development and recognizes the interdependence between communities and partners (sponsors, government, local authorities, NGOs and so forth). This implies a shift in corporate policy necessitating private companies to be more accountable and involved in contributing to community development.

In reinforcing the ideals of the above model, perhaps it is apt to end this section with the following words: "The monolithic ideology promoting neo-liberal values, such as privatisation, individuation, commercialisation and pacification must be challenged within the cultural, political and economic framework" (Rojek cited in Britton, 1991:453).

\section{Conclusion}

This paper advocates CBT projects that mirror an alternative development paradigm, which puts people at the centre of the intervention. This becomes this paper's major contribution in unpacking how international cooperation work and donor funding either influence or derail CBT projects from a path of people-centeredness to one that is in line with contemporary international neo-liberal milieu based more on private investments. This paper also posits a CBT model that articulates the role of external players and the desired characteristics of a CBT project that benefits the community with bottom-up structures, autonomy, the promotion of community cohesion, protection of the environment, and the enhancement of the health and educational well-being of communities.

The paper, using a critical view on the use of tourism (specifically CBT) in the global neo-liberalism milieu with reference to international cooperation aimed at supporting and developing a poor community, unveiled how CBT for community development can be used as an 'excuse' to foster private capital investment in marginalized and poor communities in which an international cooperation project that was initially supposed to give them full ownership and management of the project is hijacked. Partnerships, therefore, need to be evaluated in the long term and particularly in relation to holistic community development if they are intended to benefit the community. The case study used in this paper confirms that international cooperation projects seems to serve and favor private capital instead of supporting alternative approaches to development, therefore demonstrating how global neo-liberal hegemony continues to penetrate spaces and sustain its concentration instead of supporting the equitable distribution of resources. 


\section{References}

ACP-EU (The Courier). (2002). "Amadiba adventure." No 195, November-December. http://ec.europa.eu/development/body/publications Icourier/courier195/en/en_082.pdf> (Accessed 23 February 2007).

AmaMpondo Trails Brochure (n.. .) Obtained via Email from Amadiba Adventure.

Enslin, S. (2006). "Tourism ventures fail in the Wild Coast." The Sunday Independent Business report, Sunday 26 March.

Equations. 2008. Community-based rural tourism in developing countries. Some insights and lessons from the endogenous tourism project in India. In Equations, 2009. Making a difference. Dossier on community engagement on nature based tourism in India, Bangalore. National Printing Press. Available at: http://www.equitabletourism.org/files/fileDocuments837_uid13.pdf (Accessed 6 July 2011)

Giampiccoli, A. (2010). Globalisation, Development and Community-based Tourism in Developing Countries: a case study of Pondoland, Eastern Cape. Unpublished PhD thesis, KwaZulu-Natal University.

Gosovic, B. (2000). Global intellectual hegemony and the international development agenda. International Social Science Journal, 52(166), 447-456.

Hall, C. M. (2007). Pro-poor Tourism: Who Benefits? Perspective on Tourism and Poverty Reduction. Clevedon: Channel View Publications.

Hayle, C. (n.d.) Ensuring Market Realism and Effective Promotion. [On-line] Available at: http://www.mona.uwi.eduljct/aboutct /products.htm (January 31, 2011)

Lindberg, K., Molstad, A., Hawkins, D.. \& Jamieson, W., (2001). International Development Assistance in Tourism. Annals of Tourism Research 28(2), 508-511.

MTR - Mid Term Review 2003. Support to the Wild Coast Spatial development Initiative Pilot programme. Mid-term Review report project SA/99/73200/019. [On-line] Available at: http://www.environment.gov.za/ProjProg/2003jun17/sdi_review_report _17062003.html (October 25, 2004).

Norton, P. (2003). Tourism planning framework for the O R Tambo District Municipality. Supported by The EU Wild Coast Programme. Prepared by Peter Norton \& Associates cc.

Novelli, M., \& Gebhardt, K. (2007). Community based tourism in Namibia: 'Reality Show' or 'Window Dressing'. Current Issues in Tourism, 10(5), 443-479.

Ntshona, Z. \& Lahiff, E. 2003. Community-Based Eco-Tourism on The Wild Coast, South Africa: The Case of the Amadiba Trail. SLSA Research Paper 7, Brighton: Institute of Development Studies (IDS).

PondoCrop. (2002). Business plan for the Pondoland Coastal horse \& Hiking trail. EU-RSA Wild Coast Community Tourism Initiative.

Ramsa, Y. A., \& Mohd, A. (2004). Community-based Ecotourism: a new proposition for sustainable development and environmental conservation in Malaysia. Journal of Applied Science, 4(4), 583-599.

Reid, D. G. (2003). Tourism, Globalisation and Development. Responsible Tourism Planning. London: Pluto Press.

Scheyvens, R. (2002). Tourism for Development Empowering Community. Harlow: Prentice Hall.

Sharpley, R., \& Telfer, D. J. (2002). Tourism and Development Concepts and Issues. Clevedon: Channel View Publications.

Spenceley, A. (2008). 'Local impacts of community-based tourism in Southern Africa.' In A. Spenceley (ed). Responsible Tourism. Critical Issues for Conservation and Development (285-304). London: Earthscan.

Telfer, D. J., \& Sharpley R. (2008). Tourism and Development in the Developing World. London: Routledge.

Timothy, D. (2002). Tourism and community development issues. In R. Sharpley \& D. J. Telfer (Eds). Tourism and Development Concepts and Issues (pp.135-178). Clevedon: Channel View Publications.

Wild Coast community tourism initiative (n.d) EU-RSA Wild Coast programme.

World Bank (n.d.) World Bank revisits role of tourism in development. [On-line] Available at: http://web.worldbank.org/wbsite/external Inews/0,,contentmdk:20018030 menuPK:34459 pagePK:64003015 piPK:64003012 -theSitePK:4607,00.html (March 9, 2011). 